\title{
Occurrence of the Israel strain of Tomato yellow leaf curl virus and the whitefly Bemisia tabaci MEAM1 species in French Polynesia
}

M. Wong ${ }^{1}$, J. Grandgirard ${ }^{1}$, J. Hascoat ${ }^{2}$, M. Hoareau ${ }^{2}$, C. Simiand ${ }^{2}$, B. Reynaud ${ }^{2}$, P. Lefeuvre ${ }^{2}$, H. Delatte $^{2}$ and J.M. Lett $^{2 *}$

${ }^{1}$ Service du Développement Rural, Département de la Recherche Agronomique, BP100, 98713 Papeete, Tahiti, Polynésie Française; ${ }^{2}$ CIRAD, UMR PVBMT, Pôle de Protection des Plantes, 97410 Saint-Pierre, lle de La Réunion, France

*E-mail: lett@cirad.fr

Received: 10 Mar 2017. Published: 23 May 2017.

In 2014, severe symptoms of leaf curling and yellowing resembling those of tomato yellow leaf curl disease were observed for the first time on tomato (Solanum lycopersicum) plants with a $100 \%$ incidence in affected greenhouses in Tahiti (Fig. 1). Tomato samples with leaf curling and yellowing symptoms, and whiteflies were collected in Tahitian greenhouses from August 2015 to January 2016 (Table 1). Other whiteflies were collected from tomato and melon plants in Huahine and Tubuai islands.

Fourteen tomato samples were tested for the presence of begomoviruses using PCR assays with two sets of degenerate primers designed to amplify the coat protein gene of the Old World begomovirus DNA-A component (FD-CP-382/RD-CP-1038, Lett et al., 2009; Clust4CP-F342/Clust4CPR1032, Seka et al., 2016). PCR products of the expected size were obtained from all the samples, suggesting the presence of an Old World begomovirus. Direct sequencing of the PCR amplicons (669 bp) and initial sequence similarity searches using BLAST indicated that the samples were infected by Tomato yellow leaf curl virus (TYLCV, genus Begomovirus, family Geminiviridae).

To confirm the molecular identification of the begomovirus, full-length viral genomes from two PCR-positive samples (Table 1) were amplified by rolling-circle amplification, cloned using NcoI restriction enzyme and sequenced. The two genome sequences were 2,781 nucleotides in length (GenBank Accession Nos. KY656825 and KY656826) and showed the highest pairwise sequence identity, 99.3\%, (SDT; Muhire et al., 2016) with isolates of the Israel strain of TYLCV (TYLCV-IL) from Australia ([AU:Bun2:06], GU178819) and China ([CN:Sha:SH2:06], AM282874). A maximum-likelihood phylogenetic tree constructed with publicly available TYLCV sequences (MEGA6; Tamura et al., 2013), confirmed the genetic relationship of the French Polynesian isolates of TYLCV-IL with isolates from the Asia-Pacific region (Fig. 2). In parallel, total DNA was extracted from 96 female whiteflies (6 to 10 per greenhouse), sampled from different locations on each island (Table 1), to identify their species. The core region of the mitochondrial cytochrome oxidase I gene was amplified and sequenced (Thierry et al., 2011). Sequences of 598 bp were obtained for 92 samples. A single haplotype was retrieved from all three islands and showed $100 \%$ pairwise sequence identity (BLAST) with the Middle EastAsia Minor 1 (MEAM1, KM821540) B. tabaci species.

To our knowledge, this is the first report of Old World TYLCV-IL implicated in yellow leaf curl disease on tomato in Tahiti. The occurrence of B. tabaci MEAM1 species was reported in 1996-97 in Tahiti (De Barro et al., 1998), but never on the neighbouring islands of Huahine and Tubuai. This description confirms the invasion and the dissemination of both TYLCV-IL and B. tabaci MEAM1 species in the Asia-Pacific region. This report is of prime importance for the regional management of emerging diseases in these crops and for phytosanitary regulation.

\section{Acknowledgements}

This study was funded by the European Union (FEDER), the Région Réunion (Grant No. GURDT I2016-1731-0006632) and French Polynesia.

\section{References}

De Barro PJ, Liebregts W, Carver M, 1998. Distribution and identity of biotypes of Bemisia tabaci (Gennadius) (Hemiptera: Aleyrodidae) in member countries of the Secretariat of the Pacific Community. Austral Entomology 37, 214-218. http://dx.doi.org/10.1111/j.1440-6055.1998.tb01574.x

Lett JM, Lefeuvre P, Couston L, Hoareau M, Thierry M, Reynaud B, Martin DP, Varsani A, 2009. Complete genomic sequences of Tomato yellow leaf curl Mali virus isolates infecting tomato and pepper from the North Province of Cameroon. Archives of Virology 154, 535-540. http://dx.doi.org/10.1007/s00705-009-0313-0

Muhire BM, Varsani A, Martin DP, 2014. SDT: A virus classification tool based on pairwise sequence alignment and identity calculation. Plos One $\mathbf{9}$ e108277. http://dx.doi.org/10.1371/journal.pone.0108277

Séka K, Ouattara A, Assiri KP, Kra KD, Hoareau M, Lefeuvre P, Diallo HA, Lett J-M, 2016. First report of Cotton leaf curl Gezira virus and Okra yellow crinkle virus associated with okra leaf curl disease in Côte d'Ivoire. New Disease Reports 34, 8. http://dx.doi.org/10.5197/j.2044-0588.2016.034.008

Tamura K, Peterson D, Peterson N, Stecher G, Nei M, Kumar S, 2011. MEGA5: Molecular evolutionary genetics analysis using maximum likelihood, evolutionary distance, and maximum parsimony methods. Molecular Biology and Evolution 28, 2731-2739.

http://dx.doi.org/10.1093/molbev/msr121

Thierry M, Becker N, Hajri A, Reynaud B, Lett JM, Delatte H, 2011. Symbiont diversity and non-random hybridization among indigenous (Ms) and invasive (B) biotypes of Bemisia tabaci. Molecular Ecology 20, 2172-2187. http://dx.doi.org/10.1111/j.1365-294X.2011.05087.x

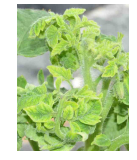

Figure 1

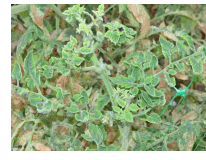

Figure 2
Figure 3

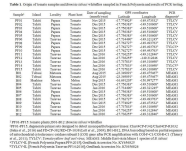

Figure 4

To cite this report: Wong M, Grandgirard J, Hascoat J, Hoareau M, Simiand C, Reynaud B, Lefeuvre P, Delatte H, Lett JM, 2017. Occurrence of the Israel strain of Tomato yellow leaf curl virus and the whitefly Bemisia tabaci MEAM1 species in French Polynesia. New Disease Reports 35, 29. http://dx.doi.org/10.5197/j.2044-0588.2017.035.029

(C) 2017 The Authors

This report was published on-line at www.ndrs.org.uk where high quality versions of the figures can be found. 